\title{
Learning to Believe in Papua New Guinea
}

\author{
Barbara Andersen
}

\section{INTRODUCTION}

If being educated is an important part of being modern-as it is in Papua New Guinea as well as elsewhere in the postcolonial world-then what is the relationship between belief in witchcraft ${ }^{1}$ and educational status? Is higher education, which relativizes "local" or "cultural" ontologies in favor of universal models of reality, necessarily a corrective to "traditional" beliefs?

In this chapter, I will consider how higher education is involved in the reproduction of witchcraft in Papua New Guinea today. While conducting ethnographic research on nursing education in a multicultural and co-educational college in the Eastern Highlands (PNG), I observed the social, religious, and epistemological practices through which students learn to make sense of the uncanny, the occult, and the demonic. ${ }^{2}$ While many of these students enter nursing education already convinced of the reality of witchcraft, their experiences as students and public servants did not necessarily change this. Media explanations for the persistence of witchcraft in PNG often note the country's low rates of higher educational achievement and scientific literacy, sometimes offering the suggestion that with knowledge of the true, biomedical causes of illness,

B. Andersen $(\square)$

Massey University, Auckland, New Zealand

(C) The Author(s) 2017

K. Rio et al. (eds.), Pentecostalism and Witchcraft, Contemporary Anthropology of Religion, DOI 10.1007/978-3-319-56068-7_10 
and death, "personalistic" (Foster 1976) explanations for misfortune will drop their hold on the imagination (Ware 2001). Such explanations ignore the wider social context of higher education, and how being an educated person can make one vulnerable to jealousy, resentment, and violence.

Upper secondary schools, colleges, and universities in PNG are important sites for the socialization of an educated elite that understands itself as distinct from the rest of the country's largely rural population-not simply because of the things they learn and the professional roles they eventually take up, but because of how the experience of education disrupts their connection to place, complicating their relationship with the potentially dangerous forces, human, and otherwise, inhabiting rural spaces. I argue that the financial demands of kin and the perceived threat of retributive violence from clients encourage health workers to see themselves as social outsiders. Students narrate their experience of higher education itself as being punctuated by occult violence and Satanic trials, which Pentecostal (and other) church social groups give them the power to resist. Pentecostalism, in this analysis, is less significant for its theological or epistemological stances than for the social function it fulfills: providing alternative forms of belonging that can mitigate the dangers of living between rural and "educated" ways of being. These encounters with diverse forms of evil can be productively mapped onto a Pentecostal universalism that demands direct intervention and resistance: an "insistence on taking control of the forces of life and death with universality as a key technique" (Rio et al. this volume, 7).

As other contributors to this volume have suggested, Pentecostal movements take a strongly practical and active stance against evil. They embrace fully the invisible world and take control of it. They describe the different forms of life and creatures that exist in it, and they offer techniques for taming it and making the invisible visible (Rio et al, this volume). Nursing education encourages a similarly practical approach to the various microscopic threats to human wellbeing, teaching health workers to make them visible and knowable to their clients. If Pentecostalism in Melanesia and Africa is "about cleaning, dividing, dissecting, observing and healing" (Rio et al. this volume, 27 ), then so too is nursing, a profession whose members frequently describe themselves as instruments of God's healing power. "We treat, 
God heals" was the motto of the students at the college where I conducted research.

Robbins (2009) suggests that Pentecostalism is unusually "socially productive" when compared with its mainline competitors. He links this productivity to how it teaches the ritualization of everyday life-techniques and linguistic formulae that any believer can draw on in order to shift the interaction frame from profane to sacred. Thus, "whenever any two or more Pentecostals are co-present, they have everything they need to engage in ritual together" (2009: 60). At nursing college, students were rarely alone and were compelled to share bedrooms, textbooks, equipment, and meals with one another. Prayer and fellowship rituals like those described by Robbins helped mediate the tensions that inevitably emerge in such close quarters. I want to suggest that witchcraft talk is another socially productive technology that helps students narrate-and thereby produce - their experiences of being "outside" or "beyond" village life.

\section{Health Education and the Problem of Tradition}

In contemporary Papua New Guinea, health workers are trained, formally and informally, to collapse almost all forms of social inequality into a distinction between homogenous "rural" or "village" people and even more vaguely characterized "educated" or "town" people. The cliché that PNG has an "85\% rural majority" has become a motto for the Department of Health, whose letterhead trumpets "Service Delivery to the Rural Majority and the Urban Poor." While there are certainly differences between rural and non-rural communities-experienced primarily in terms of unequal access to economic, social, linguistic, and cultural capital-most health workers know quite well that people can move fluidly between rural and urban spaces, lifestyles, and identities. Some of the nursing students I worked with during my research openly embraced their rural roots; and even those with the most elite backgrounds, who were perhaps second or third generation high school graduates, acknowledged their obligations to relatives in the village. However, the idea that there are "ples people" and "educated people" with fundamentally different cultures and lifeways is the central ideological construction through which the health sector reproduces its own authority. A course handout written by one of the instructors at the college describes PNG's nurses as the moral guardians of a spiritually and culturally dispossessed majority who, in the wake of colonialism's destruction of their culture, have 
also lost their conscience: "Something else must then become a real conscience, or the end result will be lawlessness. ... We must think, discuss, and pray as we work to help people understand their world. If we don't the new ideas we bring could be much worse for them than the old ideas we want to help change."

European nurses in Papua New Guinea during the colonial period thought of themselves as challengers of traditional culture, bravely facing down "native law," "fear of taboos," and the supernatural forces that held such a prominent place in indigenous explanations of illness (Kettle 1979). In the decade leading up to Independence in 1975, Papua New Guineans of both sexes were recruited to replace the European sisters and matrons that had previously held the majority of government nursing positions alongside lower ranked male orderlies and medical assistants. The assumption was (and to a certain extent remains) that these educated nationals would serve as cultural brokers between the newly independent state and the rural majority, understanding, if not actually sharing, indigenous etiologies and healing practices. Over 40 years after Independence, nurses in PNG are indeed exceptionally attentive to "customary beliefs," though perhaps not in the ways that national development planners had hoped. Rather, in the contemporary context, with quality health care largely inaccessible outside of urban areas, nurses are taught to see witchcraft, sorcery, and magic as weapons of the weak, with which rural clients can elicit recognition from neglectful others, including the absentee state and its representatives. Classroom lectures emphasized that students should always treat claims of supernatural illness as real and accountable matters: as teachers explained, "Customary belief, it can affect us, so you must entertain it. Otherwise, they will start a big war in the village and they will take the hospital to court." They taught students that the Nursing Council's professional code of ethics required acknowledging the reality of pasin tumbuna (ancestral practices). Whether the forces behind these beliefs were ontologically real or not, "If you don't respect the beliefs, the talk will come back to get you, it will hold you." Bjørn Bertelsen, in Chap. 2 of this volume, notes that contemporary witchcraft and "traditional" cosmologies share a "profoundly open nature... irreducible to stable sets of socio-cultural values, institutions and practices" (Bertelsen, this volume, 50). For my informants, the openness, and volatility of customary belief were part of what made it so frightening, and its geographical variability — what people believed and practiced could change 
from one village to the next-made set lessons on "culture" impractical. What students learned, rather, was to be vigilant and open to the possibility of "strange happenings," especially in remote places where they lacked social ties.

For many students at the nursing college, and particularly for the young women who made up approximately $60 \%$ of the student population, participation in Pentecostal fellowship groups helped them to manage feelings of dislocation and vulnerability associated with living away from family. They slept in a poorly guarded dormitory that was subject to break-ins by young men from nearby urban settlements and hamlets and faced constant sexual harassment from so-called street boysunemployed and presumably uneducated urban youths-whenever they dared to step outside the hospital fence. In this context, church fellowship groups allowed them to leave the hospital compound, to enjoy the pleasures of urban life while also preserving their reputation and safety. Student life was organized along denominational lines, with fellowship and prayer groups of wanlotu ${ }^{3}$ students providing social and spiritual support to their members. Scholars of Pentecostalism in PNG have argued that these new forms of religious membership are cosmopolitan and outward-looking, linking believers to a global community of Christians and helping to assuage feelings of marginalization and humiliation (Jorgensen 2005; Robbins 1998). Among the aspiring nurses I worked with, participation in fellowship groups granted them new opportunities for social and physical mobility in an otherwise constrained urban setting. They exchanged digital copies of music produced by Australian megachurch Hillsong and bootlegged DVDs of films about the Illuminati, the End Times, and the Mark of the Beast. They attended multiday revival camps with their wanlotu classmates and teachers, traveling to other towns and provinces and establishing social ties that spanned the country. A few even had opportunities to travel to Australia with their church groupsa distant dream for most Papua New Guineans, who despite their geographical proximity are rarely able to legally travel to their former colonial metropole without institutional support.

For many Pentecostal students, nursing college was not the first time they had drawn on their church ties for protection against evil. Their reflections on secondary schooling and dormitory life were replete with stories of supernatural happenings and occult practices. ${ }^{4}$ Here I will give just a few brief examples, though I recorded accounts of many more. Janet, remembering her high school dorm in Lae, described how the 
female relatives of students from Samarai Island ${ }^{5}$ would secretly fly pots of food to some of her classmates during the night. Janet insisted that she had always refused to partake in these witch-delivered meals, no matter how hungry she was, finding comfort through prayer instead. Here, the "traditional," place-oriented students have an economic advantage over their "believer" classmates, who in rejecting the proceeds of witchcraft suffer hunger and social isolation.

Priscilla, who had attended Port Moresby National High School, recalled an experience of possession in tenth grade which she described as a test of her faith, a consequence of her own adolescent bikhet ('bighead' disobedience) opening her up to demonic powers. She did not remember anything about the event, but her friends reported that her body went rigid and shook. "I said all sorts of things (kainkain toktok), but I don't remember. My friends called our church pastor and with my fellowship group he came and prayed over me for hours, holding me down on the bed." Finally, the demon was crushed by the power of the Holy Spirit, and Priscilla was free. Another of Priscilla's classmates, a young man, told me had left his original high school, moving to another province, to escape pressure to participate in "the generation system," a secret society that exists in upper secondary schools across the country and whose members are said to practice black magic (Api 2010; Drawii 2008). Others described cult practices as a serious problem in high schools, which they felt was threatening to students with the strong Christian faith. ${ }^{6}$ Participation in church fellowship groups gave students the power to resist the supernatural influences inherent in student social life, whether those influences were traditional (flying Samarai witches), Satanic (demonic possession), or ambiguously modern but magical (the generation system) in provenance. Like the Congolese urban spaces described by Katrien Pype, secondary schools and colleges in PNG are "fecund breeding ground[s] for new forms of occult powers," where culturally and denominationally diverse students get their first lessons in managing spiritual conflicts (Pype, this volume, 121).

While these formative school experiences convinced many students that witchcraft was a real and dangerous force in contemporary life, in the context of nursing education it is important to highlight the position of nurses as middle figures mediating between largely autonomous rural communities and a dysfunctional state. Emplacement and localitycharacteristics of the ples lain or village people who were their primary clients-were sources of deep ambivalence for nursing students. Aspiring 
to a cosmopolitan, Christian lifestyle and subjectivity, young nurses were torn between a moral imperative to bring development to their people and a desire to disavow traditional village life, with its potentially satanic ancestral practices and place-based politics. Indeed, participation in Pentecostal church groups helped them to transcend the place-linked forms of sociality associated with traditional PNG life. Church groups were proudly multiethnic, providing an alternative to what students sometimes maligned as the "wantok system"- the tendency for members of a particular language/ethnic group to socialize with one another. ${ }^{7}$ Instead of feeling morally obliged to prefer the company of their coethnics, students embraced the opportunity for fellowship and spiritual intimacy across lines of difference. While they did not reject their places of origin or their kin, they felt keenly the pressure to preferentially give their attention, wages, and care to "relatives in the village."

\section{PASin: An Undertheorized Concept}

The anthropology of Melanesia has since the 1970s explored the discourse of kastom (custom, tradition, way of life) and its encoding within legal, medical, political, and religious discourses. Most analyses of kastom have focused on its roots in colonial governance practices and its subsequent reinvention within postcolonial or de-colonial nation-building practices (e.g., Akin 2005; Keesing 1982; Thomas 1992). The emphasis in these analyses is the dialectical relationship between the construct of the "white man's ways" associated with imported institutions (law, medicine, the modern state, market economy, and Christianity) and the vernacular, indigenized practices glossed as kastom. While a lot of ink has been spilled over kastom, much less has been said about pasin, which in my own field site is intimately linked with —and often supersedes- the notion of kastom.

Pasin is a tricky term in PNG Tok Pisin. Related to the English word "fashion," it can be translated as a way of doing, behavior, manner(s) (as in good or bad manners as well as the manner of doing something), style, or tendency. All of these translations suggest that pasin is a key term within meta-pragmatic discourse: pasin is a word that describes particular kinds of doings, ranging from the habitual to the traditional to the idiosyncratic. In nursing education, pasin is used as an umbrella term (or euphemism) for witchcraft, sorcery, and associated "traditional" practices. Kastom, as it is often used in Melanesianist anthropology, tends 
to focus on overt cultural productions-symbolic practices or discourses that are primarily "about" the production of group boundaries and various levels of resistance to colonial or postcolonial forms of domination. Kastom, one could say, posits the existence of an Other to whose symbolic and institutional forms it can provide an alternative. Pasin is more malleable, and less firmly anchored to ideas of the traditional past. "Em $i$ pasin bilong mipela," it's our way of doing things, is the explanation frequently offered by rural people for activities or practices that fall outside cosmopolitan norms.

In his early writings on Melanesian kastom, Robert Tonkinson noted that while at a local level people can identify the salient images, practices, and norms of which kastom is composed, when abstracted to larger scales, like the scale of the nation-state, "the value given to kastom must necessarily be largely ceremonial and symbolic" (Tonkinson 1982: 314). The more wide-reaching the institutions involved, the more capacious and "devoid of specific content" (Tonkinson 1993: 600) the category of kastom must be. Culture/pasin, as it is taught, learned, and used by nurses in Papua New Guinea, subsumes a seemingly limitless set of prohibitions, norms, relationships, practices, taboos, and beliefs. In this respect, it bears a family resemblance to the colonial understandings of native custom that influenced the dichotomy between "custom" and "law" formalized at Independence. Nursing students spend three years or more learning specific techniques of meaning-making associated with their professional role. The vacant concept of culture/pasin that is propagated in students' textbooks and other teaching materials must be filled in through other means: through personal experiences, stories from the invisible archive of oral narrative shared within the profession, and through their collective participation in learning activities. In trying to flesh out what "culture" and "pasin" might mean for nurses as they worked within the health system, teachers drew on and elaborated students' personal repertoires of knowledge about witchcraft, sorcery, and magic-sometimes asking them to talk about experiences from their own home communities and life histories, or (more often) volunteering their own stories about occult phenomena. These stories were then reinterpreted through two distinct frames. The first, which we might call the professional frame, interpreted traditional beliefs as forms of knowledge that health workers should approach pragmatically and respectfully, understanding their significance as social "conscience." Because the majority of their clients are "rural," and hence bound to a 
different worldview, the educated health worker should accommodate their beliefs - provided they are not medically harmful - in order to show respect and avoid retribution. The second frame, invoked most often in situations where personal ethical or moral crises were discussed, was a Christian one. In such scenarios, the culture was powerful and destructive, even demonic, and could put the health worker in mortal danger.

Educational experiences create an epistemological ambivalence. Students and teachers learn that witchcraft and sorcery are real and dangerous, but whether they are personally threatening depends on one's location and relationships-not simply their beliefs. Rural settings, where pasin was alive and ubiquitous, were thus especially frightening for students-and this is a real problem when one considers the already fragile state of rural health services. Attracting and retaining qualified young public servants to poorly equipped remote health centers is difficult enough without the spiritual threats of pasin tumbuna.

In the section that follows, I describe some of the ways that students interpreted their encounters with pasin during a rural health practicum in Ivingoi, Okapa district. During the 3 -week stay in this remote community, students' anxiety about the dangers of being there became more explicit. I highlight the narrative practices through which students (and their teachers) collapsed different invisible forces into a generic evil associated with locality.

\section{Dangerous PASIN}

Yearly rural experience practicums were a welcome break from the everyday grind of classroom and hospital learning. Students looked forward to these trips all year, and the trip to Ivingoi was no exception. However, after our departure from Goroka, the excitement about being in a new place and having the chance to work in a rural health center quickly shifted into anxiety about the dangers of being out in the "bush." Among the peoples of Eastern Highlands Province, residents of Okapa-members of the Fore, Gimi, Kanite, and Keyagana language groups-have a longstanding reputation for being aggressive sorcerers. At the outset of the practicum, a student named Daniel, a North Fore speaker born near the district headquarters at Okapa Station, confessed to his classmates: "We are a really sorcerous people (mipela ol poisin lain stret). My grandfather was a poisin man. ${ }^{8}$ It's our pasin tumbuna." Students from neighboring districts knew of the region's reputation and 
had warned their classmates from other provinces that in Okapa, the pasin was still strong.

On our arrival, after a difficult 4-h drive over rough highlands roads, we discovered that we had come at the worst possible time-the funeral of a local leader was underway, and the community was deep in mourning. The funeral, and the anxieties it stirred up, set the tone for the rest of the practicum. Forced to modify their plans to comply with local pasin, the students and their tutors spent much of their time in Ivingoi discussing sorcery and witchcraft among themselves. Though students and teachers did not explicitly attribute this particular death to witchcraft (at least not to my knowledge), the mere fact that it was located in rural Okapa district summoned the specter of "pasin tumbuna".

Adding further to their anxiety, not long after arriving in Ivingoi students learned about sik kuru, the degenerative prion disease responsible for a deadly epidemic in the region during the first half of the twentieth century (Anderson 2008; Lindenbaum 1979; Whitfield 2008). Kuru, which had been spread through ingestion of human remains during mortuary rituals but was and remains emically attributed to sorcery, was a new and frightening concept to students, many of whom were unconvinced by my assurances that the disease had been eradicated. The confluence of these two events-one (the funeral) unfolding in the present, the other (kuru) in the past, but both complexly connected with pasingenerated an imaginative space that students filled with talk about their own encounters with dark forces.

From mission compound, we could see blue and black tarps fluttering over the temporary structures erected to accommodate the haus krai (mourning house ceremony). The size of the tents testified to the importance of the deceased. Pastor Allan, one of the leaders of the mission community, greeted us on our arrival and explained what was going on. A local big man and coffee entrepreneur had died suddenly, and his body was on its way back from Goroka General Hospital. Tomorrow, after the coffin arrived, it would be received in the church, and then taken into the haus krai for several days of weeping before burial. Local customs stipulated that people in mourning should not work, so we would have to wait until a respectful period of time had passed before we began our practicum. It was impossible to say how long that would be.

Pastor Allan said apologetically, “We can't work. You know, it's pasin bilong ples (our way of doing things) People wouldn't be happy. But you 
students can come sing a song at the church tomorrow when we receive the coffin, to show your sorrow." The Seventh-Day Adventist student fellowship group, who were always eager to perform, agreed and hurried off to rehearse. Sisters Wange and Biamo, our tutors, announced that we must respect the community's grief. The death of a leader meant that emotions would be running high at the hamlet level, and we did not want to get caught up in any conflict that might surface. This meant major changes to our plans for the practicum: the tutors decided that instead of going to the hauslain (hamlets) to do our community health projects, we were to stay inside the fence of the Open Bible Mission and work only with pastors' families, for our own safety.

The next day, after the ambulance arrived from Goroka with the coffin, students clustered together anxiously as it was carried into the church. Behind the coffin walked a long procession of weeping mourners, their skin, and clothes caked with the region's distinctive orange-red earth. The deceased man's close female relatives, held up by supporters as they climbed the small hill, fell to their knees in grief every few steps. We tried to keep a respectful distance.

Once everyone had crowded into the church building, the Adventist students were called forward by the pastor. Priscilla strummed the acoustic guitar while they performed two gospel songs: the first in English, the second in Tok Pisin. As the final strains of "Yu Yet Yu Bikpela Jisas (Jesus You are the Greatest)" faded away, the pastor returned to the pulpit and gave a sermon on the immortality of the soul:

Our brother has left this body, and taken another body, it is the spirit and it is inside the presence of God in God's Kingdom. Dying and rising again, Jesus opened that road, he died on the cross and this opened the road to show us, all of us men and women on this earth - those with big names, those who are money men, those who are rubbish men, all sorts of peopleall of us on this earth will die, there is only this one road that Jesus opened. Our brother here, he has taken this road. ... We can mourn, we can cry, but he is not completely dead. There will be a time when he is resurrected, just as Jesus was resurrected, and we will see and we will rejoice. Amen. This kind of [bodily] death, it is not total death. The spirit of the body that is inside your life, the Bible says this spirit will wake you again and you will be resurrected. You will leave the grave. You will take a new body. And you will become something else, as Jesus did. You will not die completely. The body can die and be finished, but the spirit today is with God in Paradise.... The Bible says here, 'The body we bury, it will rot. The body that is resurrected, 
it cannot rot. The body we bury, it's an evil thing. The body that is resurrected, it is truly good. The body that we bury, it has no strength. The body that rises, it has strength. The body we bury, it is a thing of the earth. The body that rises, it belongs to Heaven. There is the body of the earth, and the body of heaven too.

As the sermon continued, I found myself remembering what I had learned of traditional Fore and Gimi cosmology from reading ethnographies of the region: how human life force (auma or auna) had to be recycled into the forest to regenerate plants, animals, and people through song, weeping, and proper disposal of the corpse (Gillison 1993; West 2005; Whitfield 2008). The anthropologists who had documented these beliefs emphasized that the period immediately after a death was a dangerous time, when the person's homeless, wandering souls could lash out in anger and harm the living. If a person was not properly mourned, its life force would "cling to the body or hamlet forever" (West 2005: 636), causing sickness and death in the living. The Bible verses attested to a different view of death: the body was now an "evil thing of the earth," its loss a cause for rejoicing, not weeping. But if anything of traditional cosmology had survived Christian conversion, it was the danger associated with the liminal time before burial, and the atmosphere of blame and anger surrounding death.

Teachers' fears about exposing students to village conflicts meant that they would only work with particular types of rural people-those who were pastors, who lived in nuclear family households, and who lived inside the mission compound. It seemed ironic to me: the people who benefited from the labor and teachings of the nursing students were those who already lived in relatively safe circumstances and who had the advantages that came with being inside the mission fence. The hamlet was "too dangerous," its people too overwhelmed by anger and grief, too bound to pasin; the families inside the mission fence would be better equipped to daunim bel (suppress their anger) and cooperate with us.

While the leader's death created a particularly tense atmosphere, the idea that the hauslain was an intrinsically risky place because "the pasin is strong" was not unique to this occasion. I had accompanied the first year class a few weeks previously on their rural experience in a different district, and students had been vigilant about not transgressing local customs. Female students had kept a particularly close eye on their clothing, food scraps, and sugarcane skins, emphasizing that all of these could be 
used to harm them. People drew on both of the two interpretive frames described above: students expressed simultaneously a professional concern about offending their hosts' sensibilities and an individual anxiety about personal spiritual harm.

For these second year students, the death brought back bad memories of their own first year trip to Barowagi in neighboring Simbu Province. Though no one from the college had been near the vehicle at the time, they had been blamed when a local man's car was destroyed, their tutor accused of causing the crash with her "hard words." Ellen told me the story of the car crash during an interview. Their tutor, who had retired by the time of my fieldwork, had lost her temper with the pastor in Barowagi who was hosting them.

One day she 'pressurized' (presaraisim) the pastor. We went there in the dry season. The little creek we bathed in was dry, and we had to go to the big river [far away]. No water to cook either. This [tutor] went and yelled at the pastor and said, 'You people, you don't recognize when a good thing comes inside your community. If you take visitors in, you must provide for all their needs. We want to cook and it's hard. You go get water at the big river and fill up this water tank so we can cook.' She pressurized this pastor and [because] he was a pastor, he had trouble responding in this [same] kind of aggressive way... with anger inside him he borrowed the car from a local man. ... And he crashed into an ironwood tree in the coffee garden. The community came and cried, cried, came from the hamlet, came crying, crying. The car's owner cried for his car. They cried for the pastor, he was a village leader. All of them were crying and I was really afraid! Now they came and said, 'Why did you cause our man to go and do this? Why don't you settle down (stap isi)?’

The intense emotional displays of the villagers-crying over the car as though it were a person-made students fear retribution. They had been taught in the classroom and on the wards that strong emotions, especially anger and grief, could lead the ples lain to act out violently. Another student recalled how the car crash incident had made her despair for the entire enterprise of rural nursing:

At that time I was afraid. Because we were in a strange place, so it was an experience where I felt there was no hope in life. If anything happened it would still happen to us, and I was on guard. I was on guard but there was no hope, they would come and beat us or.... This kind of thought was 
with us. It was an experience I had that made me a little unwilling (les) to do rural experience. 'Why did we go so far away? Why didn't we stay at school and go out nearby, go to a settlement [in Goroka] and give health education? Why did we do this?' I thought.

Thankfully, their principal had quickly arranged to give the community several thousand kina as compensation for the damage to the car, and showed up in person to formally apologize and make restitution. Though the compensation and apology bought students safety for the rest of their time in Barowagi, memories of the incident were still strong, and likely colored students' first impressions of Ivingoi as they adjusted to the change in the program.

Our project plans on hold, we unloaded the trucks and explored the mission compound. Ivingoi Open Bible Church Mission comprised several acres of land dotted with Western-style permanent houses and a large church at the center. ${ }^{9}$ The mission, established by American missionaries in 1973, included a Bible College and the Ivingoi Health SubCenter, where we would later do some clinical work. The story we heard from one of the pastors was that the entire compound had formerly been occupied by white missionaries; however, in 2007, they had localized, leaving national pastors in charge of the mission. The health center's patch of land included quarters for resident nursing staff, a cookhouse for patient use, and an empty building in which the male students would sleep. The female students and tutors were assigned to a two-story house deep inside the mission compound, formerly a guesthouse for visiting missionaries. Because we would not be staying in the hamlets, we had access to the luxuries of an indoor bathroom (the water supply had been disconnected, so we still had to haul buckets up the stairs to bathe or flush the toilet), a gas stove, and a door with a hefty security lock.

That night, we set up our sleeping bags on cushions pilfered from the guesthouse's couches and chairs. It was much more comfortable than the bush material mats and platforms we would have slept on in the hauslain. That plus the deadbolts on the door would allow us to sleep easier. Anxious but excited, the girls and their tutors sat up for hours telling scary stories.

Storytelling is an important part of everyday sociality in PNG, both for entertainment and as a mode of sharing news and gossip. But the stories told in Ivingoi, I argue, performed an even more significant role in this particular context: they contributed to a professional archive of first-person accounts of encounters with dark forces. The context of their 
telling includes the affective tone surrounding students' rural experience trips, and their feelings of vulnerability in a remote, grieving, and potentially dangerous community. While there is no doubt that students found these stories entertaining, they were also serious business.

Ellen's story concerned a woman from Mt. Hagen, in the news recently after she confessed to drowning her six children. This story had been a regular news item in PNG for over a year. People found her story endlessly fascinating and horrifying, and women's commentary on her case often speculated that she had been driven to the act by an abusive husband. The woman was in jail awaiting sentencing, and one of Ellen's relatives, imprisoned for tribal fighting, had told her about the strange sounds he and other prisoners heard at night.

The children will come, saying 'mummy, mummy.' All of them will come and say, 'mummy, mummy.' The ghosts of the children she killed. Their spirits are restless, that's the true sign [that she killed them].

Sister Biamo, seated on the floor twisting yarn for net bags, was skeptical-not of the presence of the ghosts, but what their presence signified about the woman's guilt.

She said that her husband was a drug addict. Maybe the husband forced her to kill them, saying, 'if you tell anyone, you will die.' Whether she killed them or not, we don't know. If the ghosts of the children are crying in the prison, that's because someone has worked a satanic action. They need to investigate. People say they drowned, but why was there no postmortem? They must check their bodies.

Sister Biamo's skepticism and calls for a postmortem did not challenge the possibility of supernatural activity. Indeed, the question at hand seemed not to be whether or not the woman had killed her childrenshe had confessed as much-but who was ultimately responsible for this act, who the true agent was.

Another story, recounted by Sheena, described her personal experiences as a student at Aiyura Secondary School. Everyone was familiar with the fact that Aiyura had particularly serious problems with the "generation system" (school-based cult organizations) mentioned earlier. Seventh-Day Adventist students at the college showed a particular concern with cult activity and talked about it a lot during our interviews. 
Sheena described how a young woman in the class above her had been initiated into the system and was subjected to a sort of spiritual rape by her male classmates - they had, apparently, sent their spirits to have intercourse with her while she slept. On becoming pregnant, she procured an herbal abortion and disposed of the fetus in the school toilets. The baby's ghost, Sheena said, would slam doors in the dormitory and afflict girls with seizures and fainting fits.

One scary story led to another, and another. After giving the disclaimer, "I go to church and I don't believe in sanguma (witchcraft), but I will tell you this one story," Sister Wange told us about the time she discovered that her brother's death had indeed been caused by a sanguma, a woman whose guilt was attested to by her "unusual pasin" after the death. When the tutor's story was done, Tina, who had grown up on the border between Okapa and Lufa districts, said in a hushed voice, "These people here, in Ivingoi and nearby, they are the worst ones." If the storytelling had started out as entertainment, things had now become very serious: Tina told us about things she and her relatives had witnessed that attested to the sorcerous pasin of the Fore. As I drifted off to sleep, well after midnight, the stories were still flowing.

These stories of strange and supernatural violence were part of the atmosphere of anxiety that students struggled to contain during their stay. When the ban on work ended and students began their clinical practicum hours at the health sub-centre, they were alert to signs of "strangeness" in their clients. The odd young man staring fixedly at them as they worked? He could be mentally disabled or high on marijuana; but he could also be something else. A parturient woman from a distant hamlet laboring for hours with no improvement to her cervical dilation? After nearly a day of stalled labor, a male student asked her if there were any problems in her village - an allusion to witchcraft - that might be keeping her baby from being born. Even the revelations about kuru raised questions about the resilience of pasin tumbuna.

When an older man in the village who had been a fieldworker for kuru scientists told a student about the disease, she had been so shocked that she drove back to Goroka over the weekend, went on the internet, and printed out copies of the Wikipedia page on the disease for her classmates to read. Since I was the only person from the college who had heard of kuru before the field trip, I was asked to explain certain things about it; namely, were they at any risk? Might there be prions in the soil, in the local animals and plants, or in the latrines? Had the Fore really 
stopped eating their dead? I explained that the disease had been carefully studied and declared extinct. Fore cannibalism, I told students, was pasin bilong bipo tumbuna taim - a thing of the ancestral past - and had been decidedly abandoned. Some claimed to be unconvinced. If knowledge of the disease and of cannibalism had been kept secret for so long, there were probably other secrets to which I was not party. They knew the people of Okapa district were a poisin lain - their Okapan classmates had told them so!

Moreover, there was generally a sort of temporal slippage in remote places that meant you could never be sure that ancestral pasin was truly in the past. Because in many parts of PNG the practices classified as "pasin" or "kastom" were abandoned in performative ways at the time of conversion, they have a uniquely problematic status for Christians. Ancestral practices were not classified as ancestral because they were irrevocably in the past, left behind by the impersonal engine of historical progress, but because people had made a choice to repudiate them and become Christians. The Fore living inside the Open Bible Mission fence were probably "safe," but the ones outside the fence in the hamlets might still be secretly conducting evil pasin. As Robbins notes, Pentecostal millenarianism posits "the possibility that time with its beginnings and endings may not be continuous, that the present may not lead into the future in a predictable way" (Robbins 2001: 530). Just as one could choose to convert, one could also backslide, or "go backwards," a condition that many Papua New Guinean Christians saw all around them (see Strong, this volume). If humans were by nature both secretive and sinful, then it stood to reason that the Fore might still be up to all sorts of dangerous things.

\section{Conclusion}

Here, we can see how social and epistemological practices in higher education, informed by a Pentecostal worldview and social infrastructure, encourage the reproduction of knowledge about witchcraft and sorcery-indeed, the production of new knowledge, with new framings and implications. By creating associations and semantic linkages between different kinds of unusual death and illness associated with remote places, students give meaning to the different kinds of danger that they encounter in their personal and professional lives. Triggered by the presence of death in a strange village, and concerned about their own safety, students 
processed their fears by telling stories about first-person encounters with evil forces. Their scientific and biomedical education does not eliminate talk about witchcraft and sorcery nor relegate it solely to the status of customary belief, something that a modern person must discard in order to manifest an educated, Christian self. Rather, talk about invisible evil may be one of the socially productive technologies that Robbins describes. It allows the ethnically and regionally diverse educated classes in Papua New Guinea to analyze relations between village and town people and to make sense of their own feelings of marginality. Moreover, because they are responsible for mediating between the state and the population, they must be alert to threats of all kinds from disenfranchised people, including threats of spiritual violence. Their debates about spiritual violence, cannibalism, and the persistence of pasin out in the bush must be understood within a broader context in which Christianity and professional and class identity are intertwined.

Higher education encourages skepticism about and careful analysis of "traditional beliefs"; however, it also proliferates explanations for death and misfortune that link rural spaces and people to dangerous forces. In the case of health workers struggling to deliver services to underserved communities on the margins of the state, educational experiences amplify their own feelings of vulnerability. Some have been made ill by envious relatives or community members who resent the upward mobility granted them by their schooling (the Christmas holiday, when many secondary, college, and university students return to their natal villages, can be a particularly risky time for educated Papua New Guineans).

What then of Pentecostalism, or Christianity more broadly? Clearly, its role in affirming or challenging witchcraft beliefs is complicated in this instance since health workers learn multiple frames for interpreting misfortune. However, it is important to highlight the alternative geographies of belonging to which Pentecostal churches and fellowship groups give students to access. These support networks give them resourcessocial, epistemological, and spiritual-for resisting the dangers that they encounter during their educational and professional journeys. While the dangers come from many different quarters, their professional position encourages them to identify village life and village social organization as particularly personally threatening. Pentecostal movements and churches, like colleges and universities, are cosmopolitan spaces, offering individuals new possibilities for connection with a wider world of believers. 


\section{Notes}

1. My usage of the categories of witchcraft and sorcery in this paper is inconsistent, largely because my informants seldom used these words, preferring terms like pasin tumbuna (ancestral practices), sanguma, poisin, or bilak pawa. As Haley (2008: $270 \mathrm{nll}$ ) points out, the Evans-Pritchardian distinction between witchcraft and sorcery, while useful in some Papua New Guinean contexts, is not recognized by the law or in media reports, which tend to use "witchcraft," "sorcery," and "magic" interchangeably. The legal definition of sorcery in the 1971 Sorcery Act (repealed 2013), for example, "includes (without limiting the generality of that expression) what is known, in various languages and parts of the country, as witchcraft, magic, enchantment, puri puri, mura mura dikana, vada, mea mea, sanguma or malira, whether or not connected with or related to the supernatural" (Independent State of Papua New Guinea 1971: 1(1)).

2. This research was conducted between December 2010 and June 2012 in Goroka, Eastern Highlands Province, as part of my doctoral project, "Nursing Education and Gendered Dilemmas in the Papua New Guinea Highlands," funded by the National Science Foundation and the WennerGren Foundation for Anthropological Research.

3. Wanlotu, "one church," is a Tok Pisin word indicating membership in the same denominational group and is analogous to wantok ("one language group").

4. Because there are so few upper secondary schools in PNG, most students are boarders.

5. Samarai Island is in Milne Bay Province, while Lae is the capital of Morobe Province. As the crow (or the witch) flies, the two places are about $550 \mathrm{~km}$ apart.

6. I was told that some schools had closed their dormitories permanently due to cult activity.

7. The so-called "wantok system" is often equated with corruption and nepotism in the context of public institutions.

8. Poisin man is one term for sorcerer.

9. Open Bible Church's website states that the church is "a charter member of the National Association of Evangelicals, the Pentecostal/Charismatic Churches of North America, and the Pentecostal World Conference." https://www.openbible.org/about_discover.aspx. Accessed April 10, 2014. 


\section{REFERENCES}

Akin, David. 2005. 'Kastom as Hegemony? A Response to Babadzan.' Anthropological Theory 5 (1): 75-83.

Anderson, Warwick. 2008. The Collectors of Lost Souls: Turning Kuru Scientists into whitemen. Baltimore: Johns Hopkins University.

Api, Unia. 2010. 'Occult 'Sindaun' in a Papua New Guinea Secondary School.' Catalyst 40 (1): 65-84.

Drawii, Judy Tatu. 2008. Cult On The Rise? Students Perspective on Cult Issues In Secondary and National High Schools In Papua New Guinea. Thesis, University of Waikato.

Foster, George M. 1976. 'Disease Etiologies in Non-Western Medical Systems.' American Anthropologist 78 (4): 773-782.

Gillison, Gillian. 1993. Between Culture and Fantasy: A New Guinea Highlands Mythology. Chicago: University of Chicago Press.

Haley, Nicole. 2008. 'When There's No Accessing Basic Health Care: Local Politics and Responses to HIV/AIDS at Lake Kopiago, Papua New Guinea.' In Making Sense of AIDS: Culture, Sexuality, and Power in Melanesia, ed. L. Butt and R. Eves, pp. 24-40. Honolulu, HI: University of Hawaii.

Independent State of Papua New Guinea. 1971. Sorcery Act. Port Moresby.

Jorgensen, Dan. 2005. 'Third Wave Evangelism And The Politics Of The Global In Papua New Guinea: Spiritual Warfare And The Recreation Of Place In Telefolmin.' Oceania 75 (4): 444-461.

Keesing, Roger. 1982. 'Kastom in Melanesia: An Overview.' Mankind 13 (4): 297-301.

Kettle, Ellen. 1979. That They Might Live. Sydney: FP Leonard.

Lindenbaum, Shirley. 1979. Kuru Sorcery: Disease and Danger in the New Guinea Highlands. Palo Alto: Mayfield Press.

Robbins, Joel. 1998. 'On Reading 'World News': Apocalyptic Narrative, Negative Nationalism, and Transnational Christianity in a Papua New Guinea Society'. Social Analysis 42 (2): 103-130.

Robbins, Joel. 2001. "Secrecy and the sense of an ending: Narrative, time, and everyday millenarianism in Papua New Guinea and in Christian fundamentalism." Comparative Studies in Society and History 43 (03): 525-551.

Robbins, Joel. 2009. "Pentecostal networks and the spirit of globalization: On the social productivity of ritual forms." Social Analysis 53 (1): 55-66.

Thomas, Nicholas. 1992. 'The Inversion of Tradition.' American Ethnologist 19 (2): 213-232.

Tonkinson, Robert. 1982. 'National Identity and the Problem of Kastom in Vanuatu.' Mankind 13 (4): 306-315.

Tonkinson, Robert. 1993. 'Understanding 'Tradition'-Ten Years On.' Anthropological Forum: A Journal of Social Anthropology and Comparative Sociology 6 (4): 597-606. 
Ware, Michael. 2001. Season of the Witch, Time Pacific. May 7, 2001. Available online: http://www.time.com/time/pacific/magazine/20010507/witch. html.

West, Paige. 2005. 'Translation, Value, and Space: Theorizing an Ethnographic and Engaged Environmental Anthropology.' American Anthropologist 107 (4): 632-642.

Whitfield, Jerome, et al. 2008. 'Mortuary rites of the South Fore and kuru.' Philosophical Transactions of the Royal Society B: Biological Sciences 363 (1510): 3721-3724.

\section{Author Biography}

Barbara Andersen is Lecturer in Social Anthropology in the School of People, Environment, and Planning at Massey University, Auckland, New Zealand. Her research focuses on health care, development, and social change in the Pacific with a focus on Melanesia. She is interested more broadly in issues around inequality, space, gender, and power. Her current research examines the relationship between housing and security in Papua New Guinea.

Open Access This chapter is licensed under the terms of the Creative Commons Attribution 4.0 International License (http://creativecommons.org/licenses/by/4.0/), which permits use, sharing, adaptation, distribution and reproduction in any medium or format, as long as you give appropriate credit to the original author(s) and the source, provide a link to the Creative Commons license and indicate if changes were made.

The images or other third party material in this chapter are included in the chapter Creative Commons license, unless indicated otherwise in a credit line to the material. If material is not included in the chapter Creative Commons license and your intended use is not permitted by statutory regulation or exceeds the permitted use, you will need to obtain permission directly from the copyright holder.

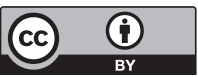

